\title{
Developing Character in Early Childhood Education Based on Constructivist Learning
}

\author{
Nurhayati \\ Early Childhood Education \\ Universitas Tadulako \\ Tadulako, Indonesia \\ line 5: email address
}

\begin{abstract}
Developing character in early childhood education based on constructivist learning is a process to transform the paradigm of constructivist learning to assess the values of character consisting of religious, honest, tolerance, discipline, hard work, creative, independent, democratic, curiosity, national spirit, patriotism, respect for achievement, friendly or communicative, love peace, love to read, care about the environment, social care, and responsibility, to the life of children. In the process of assessing values, the children must be facilitated to transform the values of character according to their real condition, both individually and socially. This process can become successful if all components learning like learning objective, curriculum, teacher, learner, activity, and learning material/media must be adjusted to support the early childhood education in developing character values themselves.
\end{abstract}

Keywords - character, early childhood education, constructivist learning

\section{INTRODUCTION}

Education is a process of developing the potential of human nature to become a better person. Education is a necessity that is essential for the growth and development of children towards a better life [1]. In the context of modern life with all the fast-paced technological developments, the speed of technological development defeats the speed of human development. So, education is present as an accelerator media for children's growth and development so that education can be regarded as an investment that fosters human resources whose value is not lower than material sources.

In its development, early childhood education has a strategic role in the development of early childhood character given that this age is an ideal age in terms of character building. As an implementation framework of character development, character education, basically, was known at the end of the 18th century which was initiated by FW. Foerster by referring to the idealist-spiritualist approach to education which is also commonly referred to as normative education theory. The birth of character education can be said as an attempt to revive the pedagogical spiritual ideal that had faded because of the onslaught of positivism pioneered by Auguste Comte, a French philosopher who was aggressively spreading positivism as the antithesis of constructivism [2]. Constructivism itself sees that character development is an effort to enable students' active participation in constructing their knowledge in accordance with their social-psychic conditions. From this description, it is illustrated that character development in early childhood education based on constructivist learning is a study of character development from a typical perspective.

\section{DISCUSSION}

\section{A. Early Childhood Education}

Early childhood education has a very important role in determining the development of a child in the next age period. A child strengthened physical and psychological development from an early age will have a greater chance of growing well than those who are not given physical and psychological development stimuli during the golden period [2]. However, the implementation of early childhood education focusing on laying the basis for physical growth and development (motoric coordination), intelligence (thinking skills, spiritual intelligence, emotional intelligence, and creativity), social emotional skills (attitude and behavior), language, and communication which is based on the uniqueness and stages of development that are passed by children [3].

According to the Indonesia's law regarding early childhood education standard, there are main goals of the early childhood education. Firstly, early childhood education is aimed to build Indonesian's children that have a good quality, who grow optimally based on their development so they can become ready before they are entering the next step of their education development. Secondly, this education system helps student to be ready in class academically in school. Based on the main concept, there are several main points in early childhood education: (1) oriented to children's need, (2) learning through playing, (3) good environment, (4) using integrated learning, (5) developing various life skills, (6) using various educational media and learning resources, and (7) gradually and repeatedly [3].

Early childhood education in concept cannot be separated from the understanding of early childhood which in the national context refers to children aged between 0 and 6 years as stated in the Law of the Republic of Indonesia Number 20 of 2003 about the National Education System in Article 1 Paragraph 14 which states that early childhood education is education intended for children from birth to age 6 years [4]. In the Law of the Republic of Indonesia Number 20 of 2003 about the National Education System in Article 1 Paragraph 14, that the age limit of early childhood is from birth to age 6 years. This age can be said to be the age of gold in children's brain development so that early childhood education has the potential to provide maximum results for children.

In relation to the principle, early childhood education is built on eight principles namely, 1) the development of self, personal, character, and children's learning abilities that are appropriate, directed, fast and sustainable, 2) education in 
terms of child development and development includes efforts to develop children's ability to develop themselves, 3) use of values living by children according to a system of values that apply to their social environment and carried out from below, 4) child education is a conscious, comprehensive, directed, integrated efforts, and carried out jointly and mutually reinforcing by all parties, 5) child education is an effort based on a social agreement which in this case is all levels of society, 6) children have a central role in development so that early childhood education has a source investment function human development in the future, 7) parents with exemplary possessions are the first and foremost actors of early childhood education communication, 8) and early childhood education must cover parent, community, and preschool formal institutions [5].

With regards to those principles applied, early childhood education has several functions. The main functions and task of early childhood education are development function, socialization function, adaptation function, and playing function. Adaptation plays a role in children adjustment from their home into their school environment. They also learn to know themselves, for example, a child from 0 to 1 year old is considered as period of adaptation. This is due to the displacement of the condition from before being in the womb to the physical condition of the outside world. Psychologically and physically, babies must adjust to conditions outside their bodies, where they have to adjust to air temperature, drinks, food, and types of clothing. In this adaptation period, of course there will be a lot of problems, especially related to the surrounding environment which causes certain illnesses such as flu, fever and cough.

Other function discussed is socialization function. This social function helps children to have social skills that can be used in the daily communication of children wherever they are. For example, in early childhood education institutions, children will meet other peers so they can try to recognize the character of their friends. Furthermore, children's emotional development will be able to develop well along with children's social development. Therefore, a balanced proportion of children's cognitive needs and child socialization is needed. Through playing together with friends, children will be able to learn social skills and communication.

Another function of early childhood education is that it can develop children's potential to the fullest. Every potential that a child has needs a situation or environment that can develop this potential in an optimal direction. Moreover, the main role of educators in this process is to develop children's potential and enrich children's learning experience. Environmental exploration and interactive activities with friends with peers, parents and the environment are ways to improve this development function.

The last function discussed is playing function. That is because the game is a natural activity that is inherent in children's daily life. Through playing activities, children are able to explore their world and can construct their knowledge. In addition, children can also practice to increase creativity. In this activity, children can also be creative by understanding how to play so that they also learn to obey the rules and also respect their playmates. The need for socialization and emotional management in game activities is very important, of course, adjusted to the level of child development.
Not surprisingly, if early age is a period that gets considerable attention from various experts in their respective fields in seeing this early age in various perspectives. Expert attention at an early age is at least based on three fundamental reasons which in this case are, 1) early age is a very fundamental age in the development of a child, 2 ) the nature of learning and development is a mutually sustainable process and continuous nature, 3) and early age education is an education that has an axiological dimension which is basically not in direct contact with the dimensions of education such as early childhood education which also functions as a place for childcare as a solution for families whose husbands are busy at work, value pragmatic early childhood education that is undeniably a promising business land, and the like [6]. Early childhood education gets great attention from various parties because it has a clear development framework both ontologically, epistemologically, or axiologically.

\section{B. Maintaining the Integrity of the Specifications}

A character becomes a basic need that begins to weaken. This was confirmed by the results of a survey conducted by Jerald Jellison, a psychologist from the University of Southern California, involving about 24,000 people with an average age of 20-30 years found that increasingly weakened character values in the present era. From the results of the survey, it was found that $41 \%$ of the respondents had driven a vehicle drunk or under the influence of narcotics, $33 \%$ of the respondents had deceived the closest person about something considered important according to personal interests, $38 \%$ of the respondents had committed fraud in the case of tax payments, $45 \%$ of respondents had committed an affair with a legal partner [7].

Before character education has been widely echoed in recent years, the values of character education, especially national character education, have been introduced by $\mathrm{Ki}$ Hajar Dewantara through the Taman Siswa Foundation in 1922 which refers to seven principles namely, 1) one's right to self-regulate with goals orderly unity in public life, 2) teaching means educating so that his inner freedom, mind, and energy, 3) education must be in harmony with life, 4) own culture that is in harmony with nature must be able to provide peace of life, 5) must work according to their own will, 6) need to live by standing alone, 7) by not being bound, born physically and mentally prepared to provide services to students [8].

Character education is essentially aimed at forming a strong, competitive, noble nation, moral, intolerant, collaborative, patriotic, dynamic, science and technology oriented, all of which are imbued with faith and piety to God Almighty based on Pancasila. Character education serves to: (1) develop the basic potential for good heart, good mind, and good behavior to strengthen and build a multicultural nation's behavior, (2) improve the competitive national civilization in world relations, and (3) character education through various media that includes families, education units, civil society, political society, government, business, and mass media.

In relation to the character values that must be emphasized in character education. There are eighteen values of character education that must be applied in each character education process: 1) religious, 2) honest, 3) tolerance, 4) discipline, 5) hard work, 6) creative, 7) independent, 8) 
democratic, 9) curiosity, 10) national spirit, 11) patriotism, 12) respect for achievement, 13) friendly or communicative, 14) love peace, 15) love to read, 16) care about the environment, 17) social care, 18) and responsibility [9].

Religious is an attitude that is obedient to religious teachings and tolerant of other religions. Honest is a behavior that is based on actions and words that can always be trusted. Tolerant is an attitude that respects the actions of different religions, ethnicities, ethnicities, opinions, attitudes and actions of others who are different from themselves. Discipline is an orderly behavior and complies with various rules and regulations. Hard work is an act that shows selfdetermination. Creative is an effort to think and do something that can produce something new or unique. Independent is an attitude and behavior that is not easily dependent on others. Democratic is a way of thinking, acting, and acting that prioritizes equality of rights and obligations. Curiosity is an attitude and action. Curiosity is an attitude that shows curiosity or wants to learn something more deeply.

The spirit of nationality is a way of thinking and acting in placing national interests above personal and group interests. Love of the motherland is a way of thinking and acting with pride and love for the nation. Appreciating achievement is an attitude and action that encourages oneself to produce achievements and appreciate the success of others. Friendly and communicative are attitudes and actions that can always foster closeness and communicative attitudes. Peace is an act that shows caring for peace and avoiding commotion. Reading is an attitude that shows the habit of providing time to read various readings that give goodness to him. Caring for the environment is an attitude and action that always cares about the environment and always develops efforts to repair the damage to nature. Social care is an attitude and action that always wants to help others in need. Responsibility is the attitude and behavior of a person who is steadfast in carrying out his duties.

Although there are 18 values forming the nation's character, the education institution should prioritize which values that are going to be main focus because it depends on the school itself. The determination from the character above is based on the interest of each institution by considering their conditions and main values on each region for example clean, neat, discipline, and polite.

Character education is very crucial for implementation of education in Indonesia because this is basic formation of nation-quality character, such as cooperative. Character education will raise superior individuals who are capable to build their character and have cognitive abilities to achieve success in their life. According to this, character education is a systematic transformation process of all the life values to be cultivated in individual's life that will be basic personality of him and it becomes the basic of their behavior. Character education is not only deal with the cultivation of values in students, but also an effort to build a good environment where they can internalize moral values that going to be used until they are adult.

\section{Developing Character in Early Childhood Education Based On Constructivist Learning}

In its historical framework, constructivism is the paradigmatic framework of the learning process first proposed by Giambatista Vico in 1710, an Italian historian, who expressed his philosophical view by stating that "God is the Creator of the universe and man is the master of creation". In its development, the philosophical view was explained that "knowing" means "knowing how to make things". This means that someone only knows something if he can explain what elements are building something [10]. Although early childhood reasoning abilities, in this case, are those between the ages of 1 to 6 years, efforts to make them know how to make things can be done by giving adjustments to the material and learning activities in early childhood which are generally very dominated by things that the nature of the game by giving constructive-recreational understanding.

As learning oriented towards directing students in constructing their understanding, constructivist learning always strives to direct the development of early childhood character through learning that does not take place in a vacuum that is independent of the social-empirical reality that surrounds it. Constructivism is a cognitive development theory that emphasizes the active role of students in building their own understanding of the knowledge they learn [11]. Constructivism in the history of education was born from the ideas of Piaget and Vigotsky. Both emphasize that cognitive development only occurs if conceptions that have been previously understood are processed through a process of imbalance in an effort to understand new information. According to Anderson in the view of constructivism, individuals are seen as constructing knowledge continuously assimilating and accommodating new information. Means that knowledge is construction or human building so that it can be said that someone who studies a knowledge means learning to construct knowledge, or learning is an active process one consumes knowledge.

Based on the application of constructivist views in learning, there are six things related to the learning environment that need to be pursued. First, by linking the knowledge that student have so they can learn through the formation of the knowledge. Second, teacher should provide learning experiences that linking the idea of student through the formation of knowledge. Third, learning experiences should be integrated and should be based on their specific task, for example, solving a problem in various way. Fourth, learning should be integrated so that enabling the social transmission. Fifth, using various media in order to make an effective communication. Sixth, engaging students socially and emotionally so that learning can be interesting.

Responding to this, constructivist learning theory as a learning paradigm requires that learning be carried out together with holistic social interactions. In this process, students construct meaning for their experience through assimilation and accommodation so that new knowledge constructs are formed because the fundamental paradigm of constructivist learning theory is the construction of new knowledge so that students are expected to become active in constructing their knowledge through giving meaning to what they learn.

Constructivism as a learning paradigm requires the active participation of students in reflecting on the learning stimuli. They receive and then negotiate them with the social-psychic reality that surrounds them. Constructivism learning theory can be illustrated as a learning approach that emphasizes 
learning by doing so that students can find the selfcompetence needed in their development [13].

In an effort to develop character in early childhood education based on constructivist learning, character values must be inserted in the various components of learning that take place so that students, in this case, are early childhood can construct new understanding of character values that are immanent in all learning components such as learning goals, curriculum, educators, students, teaching materials, and learning activities.

\section{CONCLUSION}

Character development in early childhood education based on constructivist learning is a concept of character education that sees the constructivist learning as a learning paradigm that emphasizes the ability of students to construct new knowledge from the understanding gained. In this context, character values such as religious, creative, independent, tolerance, curiosity, discipline, hard work, patriotism, honest, democratic, national spirit, respect for achievement, friendly or communicative, social care, love peace, love to read and caring the nature as well as responsibility can be directed towards the development of the independence of students in connecting with daily life.

\section{REFERENCES}

[1] I. Istadi, Istimewakan Setiap Anak, (Jakarta: Pustaka Inti, 2005), p. 54

[2] H. S. Rahman, Konsep Dasar Pendidikan Anak Usia Dini, (Yogyakarta: PG Taman Kanak-Kanak Press, 2002), p. 6.
[3] Permendiknas No.58 Tahun 2009

[4] S. Aisyah. Perkembangan dan Konsep Dasar Pengembangan Anak Usia Dini (Jakarta: UniversitasTerbuka, 2011), p. 1-3.

[5] D. Rosadi, Pendidikan Anak Usia Dini dalam Kerangka Otonomi Daerah, (Jakarta: Direktorat Pendidikan Anak Usia Dini Departemen Pendidikan Nasional, 2002), p. 51-52.

[6] Solehuddin, Konsep Dasar Pendidikan Pra Sekolah, (Bandung: Fakultas Ilmu Pendidikan Universitas Pendidikan Indonesia, 1997), p.46.

[7] T. Lickona, Educating for Character: How Our Schools can Teach Respect and Responsibility, diterjemahkan oleh Juma Abduh Wamaungo, Mendidik Untuk Membentuk Karakter: Bagaimana Sekolah dapat Memberikan Pendidikan tentang Sikap Hormat dan Bertanggungjawab, (Jakarta: Bumi Aksara, 2015), h. 18-19

[8] E. Mulyasa, Manajemen Pendidikan Karakter (Jakarta: Bumi Aksara, 2012), p. 6.

[9] A. Z. Fitri, Pendidikan Karakter Berbasis Nilai dan Etika di Sekolah, (Jogjakarta:Ar-Ruzz Media, 2012), p. 58-59

[10] Suparno, Filsafat Konstruktivisme dalam Pendidikan, (Yogyakarta: Kanisius, 2001), P. 24

[11] R. E. Slavin. Educational Psychology: Theory and Practice (8th Edition. Boston: Allyn and Bacon. 2011. P.225.

[12] H. Herman. (1998). Pembelajaran Matematika Menurut Pandangan Konstruktivistik. Makalah disajikan pada Seminar Nasional Upayaupaya Meningkatkan Peran Pendidikan Matematika Dalam Menghadapi Era Globalisasi: Perspektif Pembelajaran AlternatifKompetitif. PPS IKIP Malang.

[13] M. Thobroni, Belajar dan Pembelajaran, (Yogyakarta: Ar-Ruzz Media, 2012), P. 10 